\title{
«Y píntola en mi imaginación como la deseo»: Dulcinea entre la letra y la imagen
}

\author{
María Zambrana PÉReZ*
}

\begin{abstract}
Resumen
El estudio de las distintas representaciones de Dulcinea del Toboso y de Aldonza Lorenzo como personajes del Quijote es el propósito fundamental de este ensayo. De este modo, veremos cómo la dama, que una vez ideada por el caballero se convierte en eje y motor de nuestra historia, ha sido leída, entendida y trasladada a la pintura fluctuando según la época, sin que se consiga por tanto crear un imaginario sólido en torno a ella. En las páginas siguientes se intentará aclarar si esto se debe a que nunca aparece para desdecirse o reafirmarse en el discurso que los demás personajes realizan sobre ella.
\end{abstract}

Palabras clave: Dulcinea; pintura; imagen; ilustraciones; representaciones.

Title: «And I Picture Her in my Imagination as I Would Have Her to Be»: Dulcinea between the Letter and the Image

\begin{abstract}
The primary focus of this essay is the study of different representations of Dulcinea del Toboso and Aldonza Lorenzo as characters in Don Quixote. Consecuently, it will be shown how she, once is shaped by the knight, becomes the centre and the motor of the narrative, has been read, understood and painted according to the particular era, without having become a fully realised character. This essay will try to clarify whether this is due to the fact that she never actively appears to counteract or reinforce the discourse that other characters construct about her.
\end{abstract}

Keywords: Dulcinea; Picture; Image; Ilustrations; Representations.

* Universidad de Huelva. maria.zambrana@dfilo.uhu.es / ORCID iD: https://orcid.org/00000003-1016-4204. 


\section{Cómo citar este artículo / Citation}

Zambrana Pérez, María. 2020. "'Y píntola en mi imaginación como la deseo': Dulcinea entre la letra y la imagen». Anales Cervantinos 52: 145-166, https://doi.org/10.3989/anacer vantinos.2020.006.

A Luis y a Mercedes, por sus lecturas

Para enmarcar el estudio sobre las distintas representaciones de Dulcinea del Toboso, es necesario comenzar haciendo un brevísimo recorrido que permita poner en pie cómo y cuándo los personajes quijotescos pasan de letra a imagen. Del mismo modo, abarcaremos qué entendemos por imaginario y dilucidaremos si, en torno al personaje que nos ocupa, se ha logrado consolidar una iconografía concreta ${ }^{1}$.

La primera imagen visual de los personajes de la obra existió desde el proto-Quijote que el segundo autor descubre en Toledo [I, IX], y por ello apunta Urbina que «la tan verdadera como nueva historia del ingenioso hidalgo contenía ya en su primitiva versión en árabe alguna que otra ilustración» $(2005,37)$. Así, Cervantes introduce un primer y supuesto imaginario que debió generarse junto a la obra misma, concibiendo de este modo y literariamente ese primer manuscrito del Quijote como un todo donde la representación pictórica tiene cabida al lado de la literaria. Y, yendo un poco más lejos, Moner lo denomina libro de imágenes no por la aparición del grabado en el cartapacio, sino porque sus descripciones pictóricas se suceden a lo largo de toda la obra, presentando un alto poder sugestivo que evoca y genera la creación de las mismas (1989, 118-121).

También al respecto vale recordar la importancia que las ilustraciones tenían en una época en la que hay una mayoría de población analfabeta que no lee, sino que escucha leer ${ }^{2}$. Recordemos que, citando a Zoppi, «la definición registrada por Autoridades es precisamente la de "pronunciar lo que está escrito o repasarlo con los ojos", análoga a la de Covarrubias: "pronunciar con palabras lo que por letras está escrito"» $(2016,177)^{3}$. La representación, una

1. En este primer acercamiento acotaremos nuestro campo de estudio en aquellas ilustraciones ofrecidas por el Quijote Banco de Imágenes (QBI, 1605-1915), realizado por el Centro de Estudios Cervantinos. Asimismo, la edición citada del Quijote es la que hiciera el profesor Francisco Rico para la Real Academia Española, editorial Alfaguara (2005).

2. Así, el capítulo II, LXVI, lleva por título «Que trata de lo que verá el que lo leyere o lo oirá el que lo escuchare leer». No será esta la única referencia de la obra a los distintos tipos de lectura posibles: si bien es cierto que Alonso Quijano acaba haciéndose don Quijote por lectura individual, también lo es que las novelas de caballerías, en palabras de Miguel-Pueyo, «solían leerse en forma colectiva. Hasta se los aprendían de memoria para recitarlos» $(2006,470)$ y que, por tanto, el hidalgo no sería un ejemplo representativo de cómo se accedía, de forma mayoritaria, a este tipo de textos. Concluye Zoppi que el Quijote fue una obra concebida más para ser oída que leída, pues «establece (con el lector) una participación diferente, fundada en otro modelo comunicativo» $(2016,179)$.

3. Es importante remitir aquí a Zumthor (1991a, 1991b, 2006) y a Frenk (2005). En el caso del primero, resulta interesante su concepto de performance, que no es sino «la acción vocal en virtud de 
vez leído o escuchado el texto, ayudaría a consolidar ese imaginario que podría perderse o deturparse de no haber un acercamiento directo a la obra 4 . Señala Urbina al respecto que la iconografía habría ayudado a que los personajes resultasen fácilmente reconocibles dentro de un modelo en cualquier época, de manera independiente a la aproximación individual a la novela (que sería suplantada por ese imaginario colectivo en el mayor de los casos).

Por todas estas cuestiones apuntadas, las distintas imágenes del Quijote no son solo un elemento clave para darle privilegio a una lectura concreta, sino que con ellas se aceleran los procesos de formulación y canonización de la obra misma. Explica Lucía Megías en su «teoría de la lectura coetánea» ${ }^{5}$ que las imágenes cumplen tres importantes funciones dentro de un texto: destacar «determinados episodios, aventuras e, incluso, personajes», complementar «una lectura, una determinada interpretación de aquello que se está narrando y que el receptor está oyendo o escuchando en un momento histórico particular», e interpretar «la voz y la letra en gestos, formas y, en ocasiones, colores, gracias a un particular lenguaje» (2006, 39-49).

En cuanto a las representaciones de la obra misma, no deja de sorprender que las primeras sean tan cercanas a la fecha de publicación de la novela: pertenecen a la mano de Andreas Bretschneider y se trata de una serie de grabados fechados en $1614^{6}$. Nos parece interesante apuntar el bucle irónico que resulta de ello ${ }^{7}$ : don Quijote se viste como los personajes de las ficciones

la cual el texto poético se transmite a sus destinatarios», configurándolo -o, en nuestro caso, pintándolo- en un cuerpo a través del efecto sonoro y del gesto del que lee (1991a, 21).

4. La importancia de la imagen para quien no lee, o para quien se está formando en la lectura, no es algo únicamente propio del siglo XVII. Para Genette, no será hasta el siglo XIX cuando se empiece a debilitar la lectura colectiva $(1969,124)$. De ahí que las aleluyas -pequeñas representaciones acompañadas de dos versos en rima consonante de los momentos más representativos de la obrajugaran un importante papel, ofreciendo «una instrucción rudimentaria a los lectores menos cultos y generalmente iletrados, adultos y niños, que a través de aquellos impresos baratos recibían muchas veces sus primeros conocimientos sobre personajes, hechos históricos, arte, literatura, etc., situados fuera de su panorama vital» (Martín 2011). El banco de archivos de la Biblioteca Nacional de España tiene digitalizadas algunas de ellas, que van desde el siglo XVIII hasta mediados del XX, en idiomas como español, francés y catalán.

5. Definida por él mismo como un intento de «organizar un sistema de recogida de datos para que, desde diversas perspectivas, podamos llegar a precisar la "lectura coetánea" de una obra en un determinado momento, o a lo largo de su transmisión» $(2006,39)$. Ejemplo de ello es que «en sus primeros siglos de difusión y éxito descubrimos unos personajes particulares, cercanos a los modos de vestir y de comportamiento de sus lectores (...): don Quijote y Sancho Panza se vuelven franceses, ingleses, alemanes según el lugar del que se hacen letras de molde sus aventuras» $(2006,20)$. Sírvanos como ejemplo el tratamiento dado a los molinos de viento en los distintos países, pues según su acepción cultural se ven representados de distintos modos. Véase al respecto Alonso Vázquez (2007).

6. El grabado consta de cuatro cuadros: el primero, donde vemos al enano, cura y barbiera; el segundo, con Dulcinea y don Quijote; el tercero, con el escudero, la linda Maritornes; el cuarto, con el carruaje. Cura y barbero «portan dos objetos que se relacionan con dos aventuras que tienen un elemento en común: don Quijote se enfrenta a lo que él considera gigantes, pero que en realidad son molinos de viento y cueros de vino (aquí representados por un tonel)» (Lucía Megías 2006, 111).

7. Entendemos aquí categoría irónica como la formulara F. Schlegel, pues adquiere entonces «un carácter dialéctico indefinido y progresivo, casi infinito» (Benéitez 2016, 40). Así, «en ella todo debe ser broma y todo debe ser serio, todo debe resultar cándidamente sincero y profundamente simulado 
que lee, esto es, se disfraza; del mismo modo actúan los lectores de sus historias. En palabras de Comellas, y como se entendía en el Romanticismo, «al destruir los entresijos de la ficción literaria se logra también (...) mostrar que las sólidas estructuras de la realidad pueden desmoronarse al enfrentarse con la esfera imaginativa» $(2002,282-283)$. Interesa también lo temprano de la fecha: no se ha publicado aún la segunda parte de la historia caballeresca, y los personajes que aparecen pertenecen todos a la entrega de 1604. El tercer aspecto que señalaremos -y el más importante para nuestro propósito- es que hallamos ya una representación de Dulcinea, grabada como la «soberana y alta señora» de ropajes pomposos, precediendo a don Quijote en la comitiva festiva y con la inscripción, sobre ella, que reza «la sin par Dulcinea del Toboso».

En la materia que nos ocupa, aclararemos qué concebimos como «imaginario». Explica Gutiérrez que el imaginario, en definitiva, sería un puente entre lo sensible -lo que vemos- y lo inteligible -lo que representamos-. La imagen, de este modo, consistiría en la representación mental de la combinación de esos dos mundos, y la imaginación se serviría para ello de una primera imagen -la sensible-, a fin de reelaborarla (2012, 32-34).

Lo que ocurre con Dulcinea es que, si adoptamos la terminología de Gutiérrez, se trata de una «imagen simbólica» ${ }^{8}$, esto es, a los lectores se nos presenta carente «de entidad material (...). Su aprehensión, por distintos motivos, resulta muy dificultosa» $(2012,34)^{9}$. En la misma línea, Julio Torres la denomina «personaje elíptico» (1997), pues presuponemos su existencia, pero no la vemos en el texto. Por ello, podemos entender, surgen problemas en torno a su representación pictórica ${ }^{10}$; de ahí también que resulte más sencilla iconográficamente su plasmación mediante el personaje de Aldonza Lorenzo -imagen totalmente sensible, aunque tampoco llegue a aparecer físi-

a la vez» (Schlegel 2009, 49). Cabe recoger aquí las palabras de Albert: «No interpretation can exhaust the meaning of the ironic text and bring it to the rest: there will always be an aspect of it that none of the successive readings, no matter how comprehensive or sophisticated, will be able to take into account» $(1993,829)$.

8. Llama «imagen simbólica» a aquello que Durand denomina «símbolo», pero justifica esta distinción alegando que, mientras el «símbolo» se enmarca en la actualización, la «imagen simbólica» se constreñiría en la abstracción. Aceptamos su propuesta en tanto que, para el caso concreto que nos ocupa, hemos de partir de lo abstracto. Podemos relacionar la imagen simbólica con la asociación que Canga hace de Dulcinea y la idea de «fantasma» de Freud. Explica que «el fantasma es para el psicoanálisis una producción imaginaria que responde al deseo de obtener una satisfacción que la realidad no proporciona. En sus primeros trabajos, Freud calificaba tales fantasías como "sueños diurnos", puesto que se parecen mucho a los sueños, pero se producen en estado de vigilia, mientras el sujeto permanece despierto (...). La poesía, señalaba, al igual que los sueños diurnos, es la continuación y el sustitutivo de los juegos infantiles, y el verdadero arte poético reside en la técnica de superación de la repugnancia y la vergüenza que producen las simples fantasías del hombre normal» $(2008,220)$.

9. Sin embargo, para don Quijote sí podría partir Dulcinea de una imagen sensible, esto es, concebible físicamente, si aceptamos que nace de Aldonza Lorenzo. Una vez creada, se distanciaría de ella. Para más, véanse Allen (1990), Gorla (2009) y Lamberti (2011).

10. Para Lacan, «el amor es un fenómeno que ocurre a nivel de lo imaginario, y que provoca una verdadera subducción de lo simbólico, algo así como una anulación, una perturbación de la función del ideal del yo» $(1995,215)$. 
camente- o mediante la sucesión de imágenes que responden a códigos literarios ya establecidos.

Don Quijote es consciente de esta dificultad. Si bien en la primera parte de la obra las descripciones de la dama se basan precisamente en la acumulación de tópicos -sírvanos como ejemplo la conversación tan citada con Vivaldo [I, XIII]-, en la segunda, la entidad de Dulcinea se complica. Así, en su estancia con los duques, se señala como su primer retratista en tanto que la dama forma parte de él, emparentándose así con el verso de Garcilaso que reza «escrito está en mi alma vuestro gesto»:

Si yo pudiera sacar mi corazón y ponerle ante los ojos de vuestra grandeza, aquí sobre esta mesa y en un plato, quitara el trabajo a mi lengua de decir lo que apenas se puede pensar, porque Vuestra Excelencia la viera en él toda retratada [I, XXXII, 798 $]^{11}$.

Todo ello nos lleva a apuntar ya en esta introducción de la materia que la Dulcinea de don Quijote es un ser más abstracto que concreto.

Lo primero que llama la atención cuando nos detenemos a estudiar las representaciones de Dulcinea es su escaso número en comparación con las 11452 de don Quijote o las 9678 de Sancho Panza, incluso de otros personajes menores: de la señora del Toboso, 384 son las imágenes halladas; en el caso de Aldonza Lorenzo, se reduce a $193^{12}$. Hemos de tener en cuenta aquí que las cifras son engañosas por varios motivos; en primer lugar, porque la separación de ambos actantes no es algo tajante y el hecho de que se indique que una imagen corresponde a un personaje $u$ otro no garantiza que cuando acudamos a la representación encontremos tal relación entre lo indicado y lo ilustrado, pues se trata en el mayor de los casos de forma indistinta a la aldeana y a la dama. Por otro, porque según los modelos de los talleres ${ }^{13}$, las imágenes se suceden sin apenas variantes en muchos de los casos en distintas ediciones. Esto último permite la consolidación de un imaginario concreto en torno a un capítulo, pero también implica que esa lectura o esas imágenes se fosilicen.

Acudiendo a casos determinados, el capítulo II, X (encantamiento de Dulcinea por parte de Sancho Panza) se repetirá en 201 imágenes de las 384 recogidas en el catálogo (Fig. 1) ${ }^{14}$.

11. Idea ya insinuada en el Quijote de 1605 , cuando el caballero confiesa a Sancho que la "pinta" en su imaginación como la desea.

12. Todas ellas recogidas por Quijote. Banco de Imágenes (2005).

A su vez, hallamos apartados específicos para el Caballero de los Leones (un total de 255), el pastor Quijótiz (16) y Alonso Quijano (441). En el caso de Sancho, se le representa como gobernador en 833 imágenes; en 16 como pastor Pancino.

13. Se distinguen cuatro talleres (holandés, francés, inglés y español). Para más, véase Lucía Megías (2006).

14. Edición de 1657, grabado. Dibujante y grabador: Jacob Savery. 


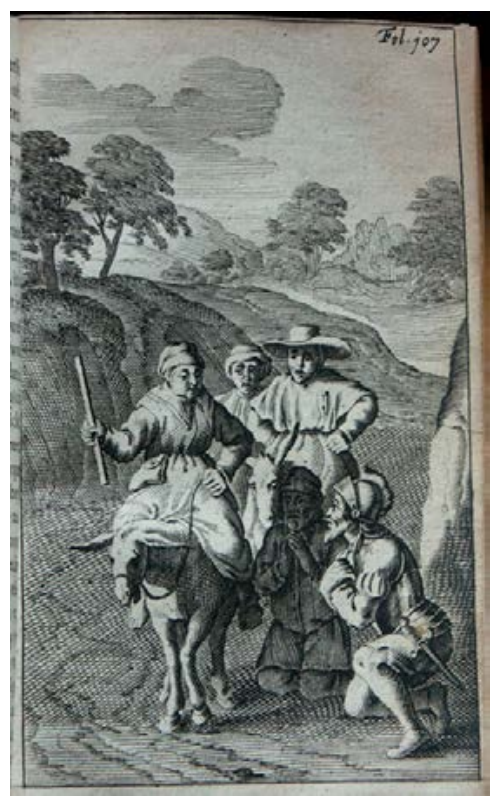

FiguRA 1. Jacob Savery, 1657.

Esto quiere decir que aproximadamente el $52 \%$ de las ilustraciones responden a un mismo episodio, lo cual reduce bastante sus variables temáticoiconográficas. Sin embargo, el problema no recae tanto en que más de la mitad de las imágenes se refieran a un único capítulo, sino en que la Dulcinea supuestamente representada no es, verdaderamente, ni Dulcinea ni Aldonza. $\mathrm{Si}$ acudimos al texto escucharemos la voz de Sancho, que hablando a solas se plantea cómo salir de la situación en que le ha puesto su amo:

Siendo, pues, loco, como lo es, y de locura que las más veces toma unas cosas por otras y juzga lo blanco por negro y lo negro por blanco (...) no será muy difícil hacerle creer que una labradora, la primera que me topare por aquí, es la señora Dulcinea [II, X, 616].

Como vemos, Sancho ha entrado en el juego del caballero y, conociéndole, es capaz de adelantarse al razonamiento que seguirá don Quijote en esta situación dada: la justificación de que no estemos ante Aldonza o Dulcinea recae en un encantamiento.

Otro de los capítulos más ilustrados en lo concerniente a Dulcinea del Toboso nos presenta el mismo dilema: se trata del II, XXXV, en el que supuestamente se presenta la dama a don Quijote durante la estancia del caballero con los duques ${ }^{15}$ (encargados, en este caso, de orquestar un engaño doble) (Fig. 2) ${ }^{16}$.

15. Como curiosidad, será en España en 1755 donde por primera vez se ilustre este episodio.

16. Edición de 1757, grabado. Dibujante: Diego Obregón, grabador: anónimo. 


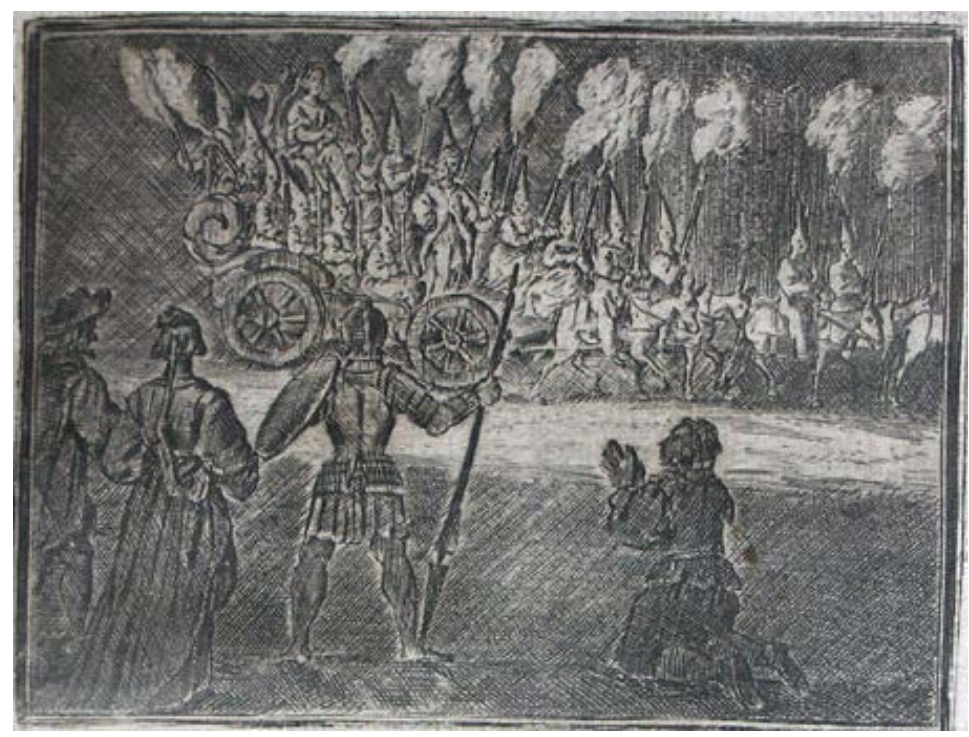

FiguRA 2. Diego Obregón, 1757.

En ambos casos, el título de los capítulos introduce el nombre de Dulcinea -cuando, recordemos, no se trata en ninguno de los casos ni de ella ni de Aldonza, puesto que se trata de una mentira- y creemos que esto influye en que se vea representada y recogida bajo esta etiqueta ${ }^{17}$. Pese a que responderían, efectivamente, a una Dulcinea falsa creada por Sancho en el momento del engaño y a otra creada por los duques en el momento en el que da la solución para el desencantamiento ${ }^{18}$, no podemos recogerla aquí en tanto que como lectores somos conocedores de la burla, y en ningún tiempo se nos hace víctimas de ella.

A partir del Romanticismo, otros capítulos hasta entonces no representados comienzan a grabarse. Los más repetidos son la embajada a El Toboso en el I, $31^{19}$ y la búsqueda de Sancho de la dama en el II, 9 (Figs. 3 y 4$)^{20}$.

17. «Donde se cuenta la industria que Sancho tuvo para encantar a la señora Dulcinea, y de otros sucesos tan ridículos como verdaderos» $\mathrm{y}$ «Donde se prosigue la noticia que tuvo don Quijote del desencanto de Dulcinea, con otros admirables sucesos», respectivamente.

18. Sancho, además, será el encargado de consolidar la imagen física que tenemos de Aldonza a partir del I, XXV. Recordemos que el primer autor del Quijote nos la había definido como «moza labradora de muy buen parecer» [I, I]. Todas estas contradicciones dificultan la imagen que, como lectores, vamos fraguando de ella.

19. Edición de 1836-1837, viñeta. Dibujante: Tony Johannot, grabador: Pierre Verdeil.

20. Edición de 1836-1837, viñeta. Dibujante: Tony Johannot, grabador: anónimo. 


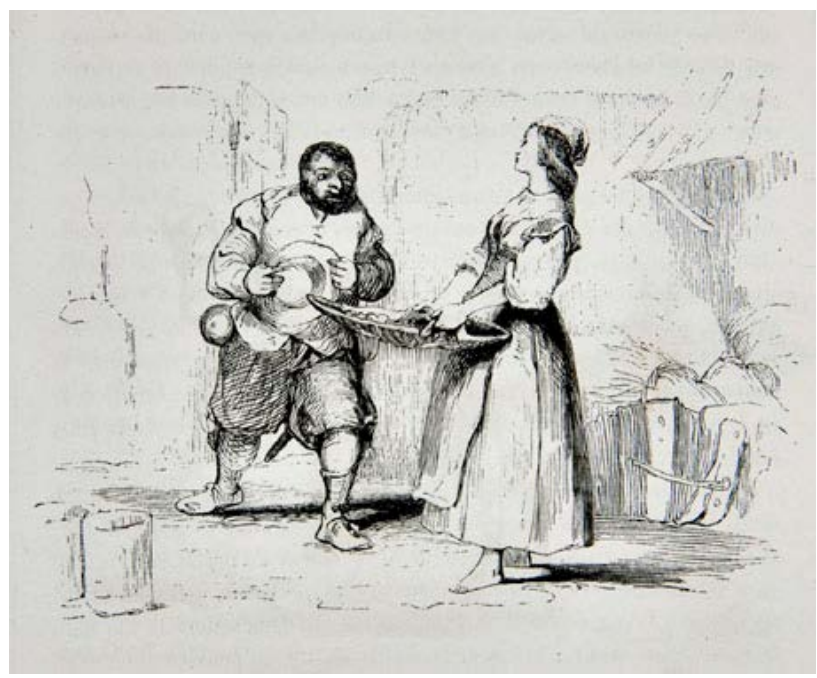

FIGURA 3. Tony Johannot, 1836-1837.

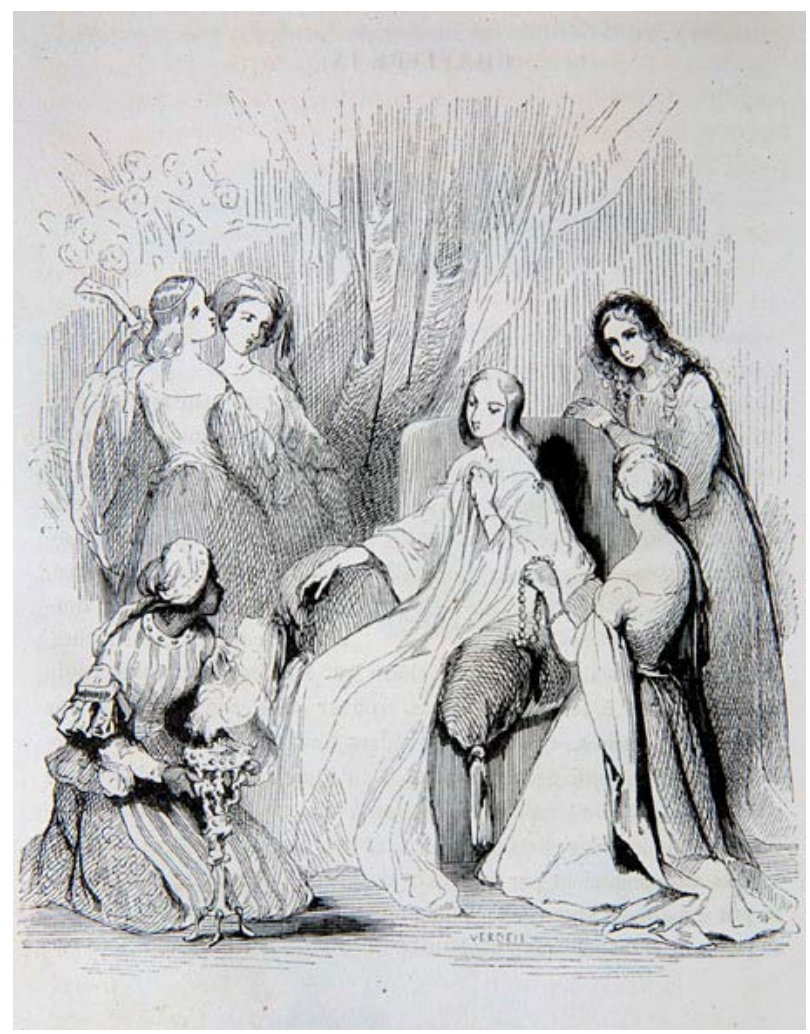

FIGURA 4. Tony Johannot, 1836-1837. 
Hemos de destacar aquí que si en ninguno de estos episodios de la novela se produce un encuentro real con Dulcinea, tampoco se producirá con Aldonza, personaje que no llega nunca a mostrarse físicamente en ninguna de las dos partes que configuran la obra. Baste ahora recogerlos brevemente.

En el primero de los episodios mencionados vemos representada la mentira que Sancho cuenta a don Quijote sobre su encuentro con Dulcinea, a quien descubre «ahechando dos hanegas de trigo en un corral de su casa» [I, XXXI, 311], como se nos muestra en la imagen ${ }^{21}$. Recogeremos estas ilustraciones como ex nihilo in fabula, pues son episodios que no suceden realmente en ningún momento de la obra más allá del pensamiento de los personajes ${ }^{22}$.

La búsqueda de Dulcinea sería la tercera mayor fuente de grabados del personaje en lo que a representación de capítulos se refiere -pues, como veremos, hay una extensa gama de frontispicios con este motivo-. Pese a que en el texto cervantino la entrada en el Toboso la hacen amo y escudero y no visitan ningún palacio, en las representaciones sí aparece Dulcinea en este supuesto escenario que no responde sino a la narración que había hecho Sancho en el capítulo XXXI de la Primera parte. Sería también una creación ex nihilo in fabula, pues es un momento descrito en la obra, pero no un hecho real.

Tanto este capítulo como el anterior están íntimamente relacionados: en él se vienen a hacer ciertos los temores de Sancho de ser descubierto por su anterior mentira en la embajada a El Toboso, y como vemos, el imaginario creado en torno a estos dos episodios responde únicamente a lo dicho por el escudero.

Cuestión aparte son los retratos. En este sentido, hemos de diferenciar los retratos de Aldonza Lorenzo, los que confunden a ambos personajes (esto es, en los que hay algún tipo de interferencia y sus cualidades fluctúan) y los de Dulcinea propiamente dichos -que comentaremos más adelante- . Con diferencia, los más numerosos serán, bien los mixtos, bien los de la aldeana, pues suponen una menor dificultad en cuanto a la plasmación.

Resolveremos pronto que, para el primero de los casos, el retrato de Doré nos daría una idea de las pautas que siguen sus representaciones - continuadoras de la estela de la descripción física que estaría a medias tintas entre la de Cide Hamete («Esta Dulcinea del Toboso, tantas veces en la historia refe-

21. El propio Sancho reconocerá más tarde este engaño: «Que también fue de oídas la vista y la respuesta que le truje; porque así sé yo quién es la señora Dulcinea como dar un puño en el cielo» [II, IX, 611].

22. Esto es, no nos es narrado por el autor como si de un hecho real (dentro de la ficción) se tratara. Diferenciamos entre ex nihilo in fabula y ex materia dado que nos parece más cómodo de cara a ofrecer una catalogación de las ilustraciones. Así, extrapolando a este contexto las palabras de Ricoeur, las ilustraciones ex nihilo in fabula se vincularían con la imaginación, «dirigida hacia lo fantástico, la ficción, lo irreal, lo posible, lo utópico», mientras que las ilustraciones ex materia tendrían que ver con la memoria, y se dirigirían más bien «hacia la realidad anterior, ya que la anterioridad constituye la manera temporal por excelencia de la "cosa recordada", de lo "recordado" en cuanto tal» $(2003,22)$. 
rida, dicen que tuvo la mejor mano para salar puercos que otra mujer de toda la Mancha» [I, IX]) y la ofrecida por Sancho en Sierra Morena (Fig. 5) ${ }^{23}$.

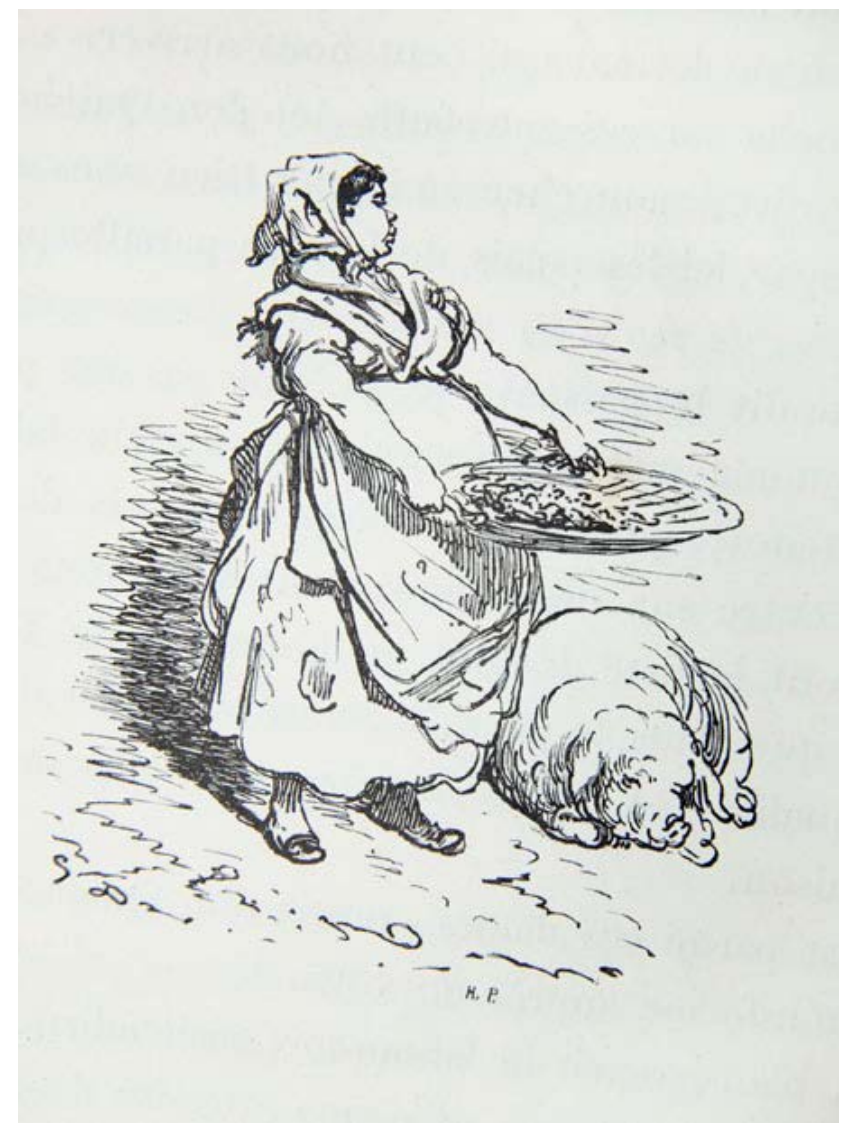

FiguRA 5. Gustave Doré, 1863.

Curiosas son dos ilustraciones de Dulcinea que, pese a no ser retratos, merecen un comentario. La primera es una creación ex nihilo in fabula, pues es un momento que no aparece en la obra como algo real -solo existe como miedo de don Quijote-. Ilustra el capítulo I, 25 por primera vez en el año de 1836, y nos muestra el supuesto final de la penitencia del caballero en Sierra Morena (Fig. 6) 24 . 


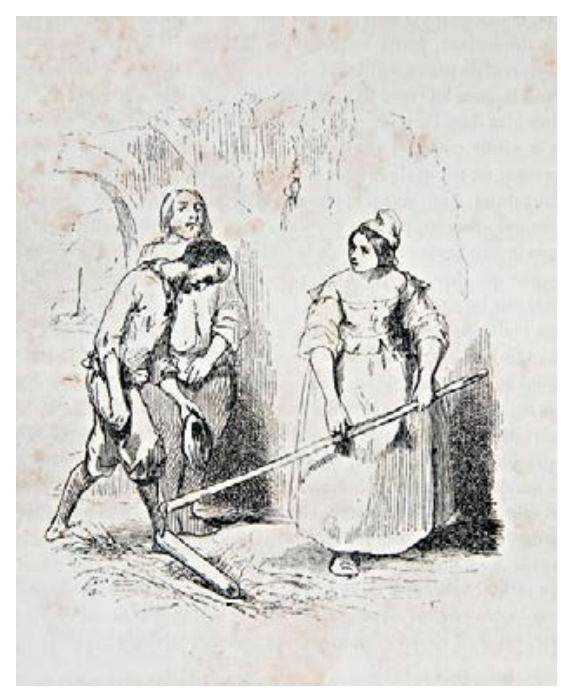

FiguRA 6. Tony Johannot, 1852.

La segunda de ellas se ilustrará en España en 1905 y es creación ex materia - esto es, se basa en lo dicho y, más concretamente, en lo dicho sobre un pasado que presuponemos fue real-. Responde así al momento en que Alonso Quijano anduvo enamorado de Dulcinea: el ilustrador imagina así que acudía a verla a hurtadillas: «En un lugar cerca del suyo había una moza labradora de muy buen parecer, de quien él un tiempo anduvo enamorado, aunque, según se entiende, ella jamás lo supo ni le dio cata dello» [I, I, 33] (Fig. 7) ${ }^{25}$.

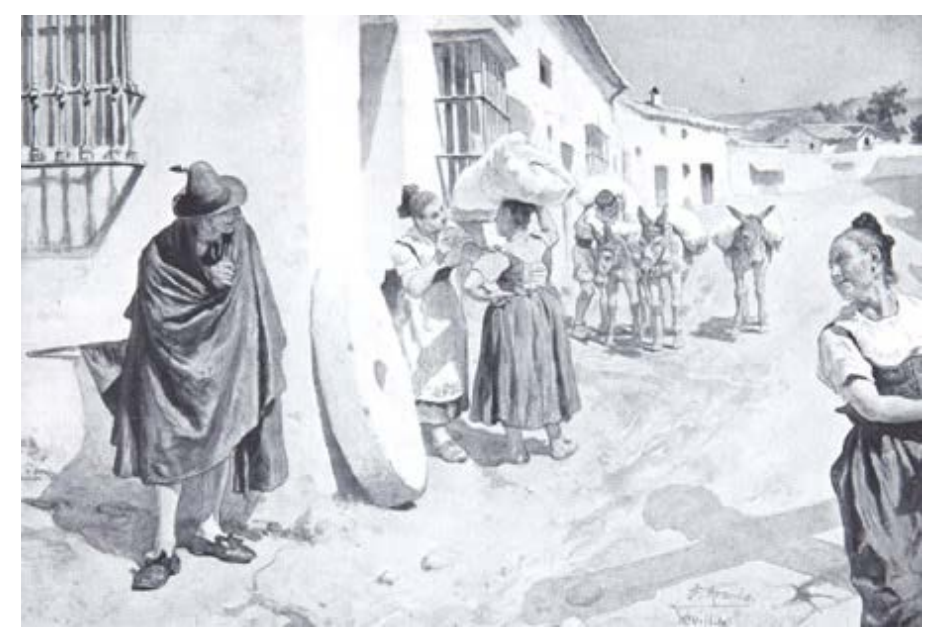

FIgURA 7. José Jiménez Aranda, 1905-1908.

25. Edición 1905-1908, grabado. Dibujante: José Jiménez Aranda, grabador: anónimo. 
En cuanto a los retratos de Aldonza-Dulcinea, si observamos la imagen, advertimos que a pie de foto se lee «Retrato de Dulcinea», pero que la representación corresponde más bien a la descripción física que sigue la estela que de ella hiciera Sancho (lo cual respondería a la imagen supuestamente de la aldeana, aunque no podemos asegurarlo en tanto que tampoco aparece nunca en las páginas del texto) (Fig. 8) ${ }^{26}$.

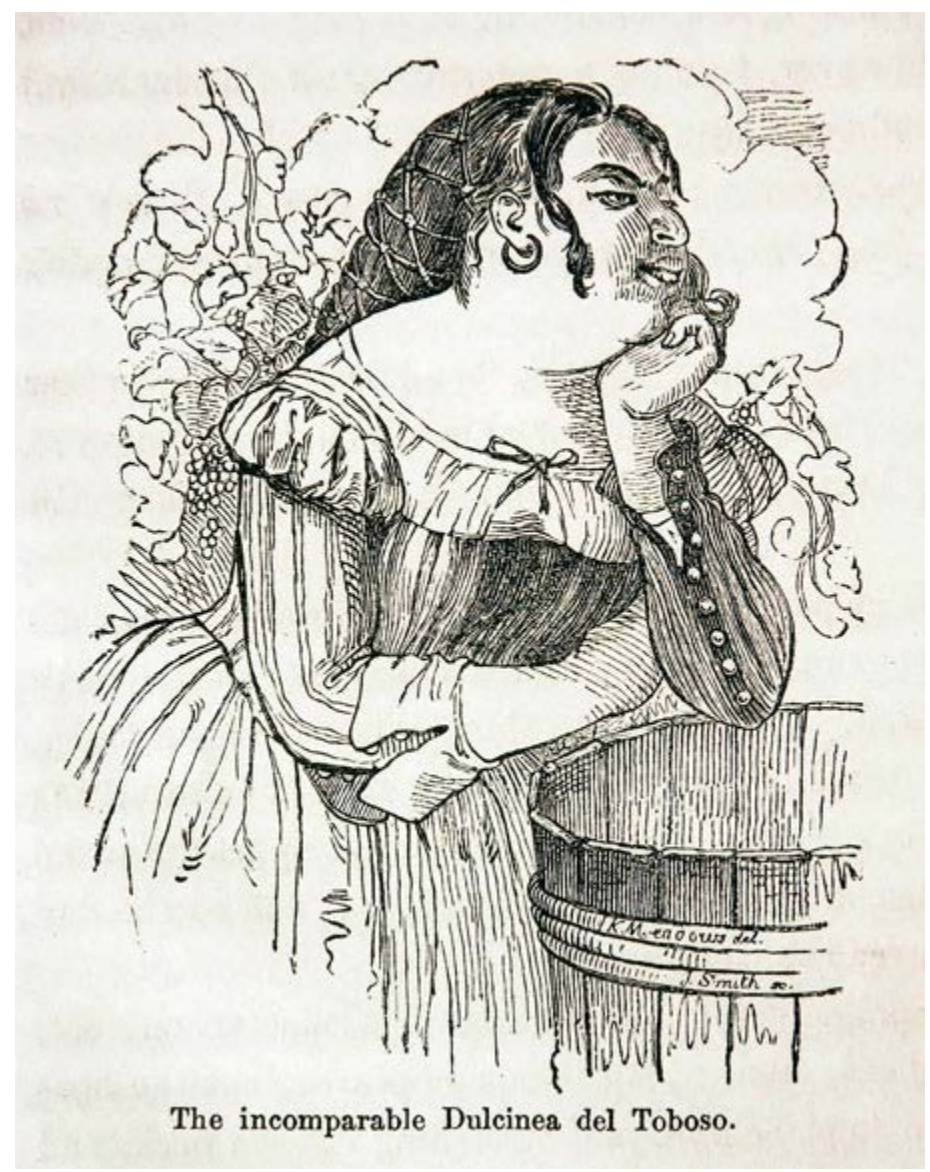

Figura 8. Joseph Kenny Meadows, 1833.

El segundo retrato seleccionado nos muestra nuevamente a Dulcinea: en esta ocasión no hallamos los rasgos descriptivos ofrecidos por Sancho, pero por sus ropajes, los objetos y el escenario en el que se sitúan la entendemos como campesina y no como la alta señora que es para don Quijote. Por tanto, tampoco entraría en la idea que el caballero nos da de ella (Fig. 9) ${ }^{27}$. 


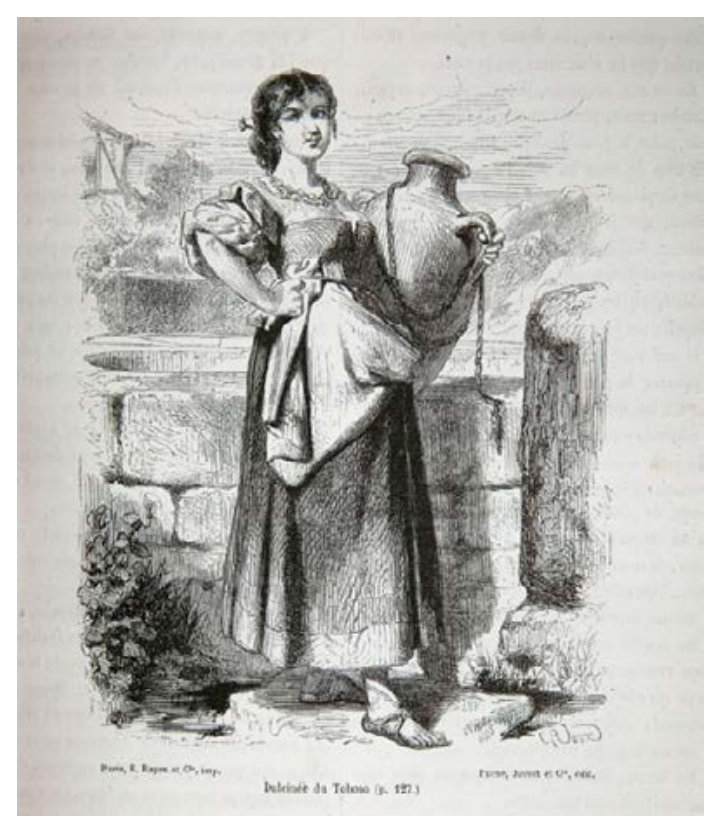

FIGURA 9. Georges Roux, 1866.

Observando tanto los capítulos más representados como los retratos, podemos afirmar que desde el siglo XIX se da un viraje y comienza a entenderse a la aldeana como Aldonza, mientras que el intento de pintura de dama elevada es el que entra dentro de la etiqueta de Dulcinea del Toboso, bien responda al esquema creado por Sancho u otros personajes (capítulos I, XXV; I, XXXI; II, IX y II, XX), bien al esquema extraído de lo leído en los libros de caballerías.

Es precisamente dentro de esta idea donde nos situamos ahora, y catalogaremos las imágenes que tratamos en frontispicios ${ }^{28}$, imágenes especulares y retratos.

Los frontispicios son el primer tipo de grabados que hallamos acompañando el texto que nos ocupa. Previamente, recordemos, se había plasmado en papel al personaje de Dulcinea para una celebración en Leipzig; sin embargo, no encontraremos una consolidación de su imagen hasta que no se haga común la colocación de una página principal representando gráficamente a los personajes principales de la obra ${ }^{29}$.

Nos detendremos, en este sentido, en la lectura que hace Luttikhuizen de los frontispicios que acompañan la primera y la segunda parte del Quijote (Fig. 10), pues la confrontación de ambos representaría la dualidad existente

28. «Página de un libro anterior a la portada, que suele contener el título y algún grabado o viñeta», Diccionario de la Lengua Española, 23. a edición (2014).

29. La primera edición ilustrada es la de Dortrecht, y ya incluye frontispicios. 
en el personaje, que no es sino la propia incompatibilidad de convivencia de dos seres en uno (o en una misma lectura, si se quiere):

En el frontispicio de la primera parte Dulcinea, flanqueada por Amadís y Roldán, aparece bella (símbolo de la mujer idealizada), pero encantada, prisionera de su belleza (simbolizado por el marco) y prisionera de los antiguos cánones (simbolizado por Amadís y Roldán). Por el contrario, en el segundo, Dulcinea y Sancho Panza - dos personajes realistas- custodian al mago Merlín, el culpable de los engaños (aprisionamiento simbolizado también por el marco). En esta segunda imagen, Dulcinea, desencantada, aparece real y tal como es, fea y gorda, una verdadera aldeana. En el primer frontispicio, don Quijote aparece listo para salir a enderezar entuertos; en el segundo, aparece ya triunfante y con el título de Caballero de los Leones $(2008,295-296)^{30}$.

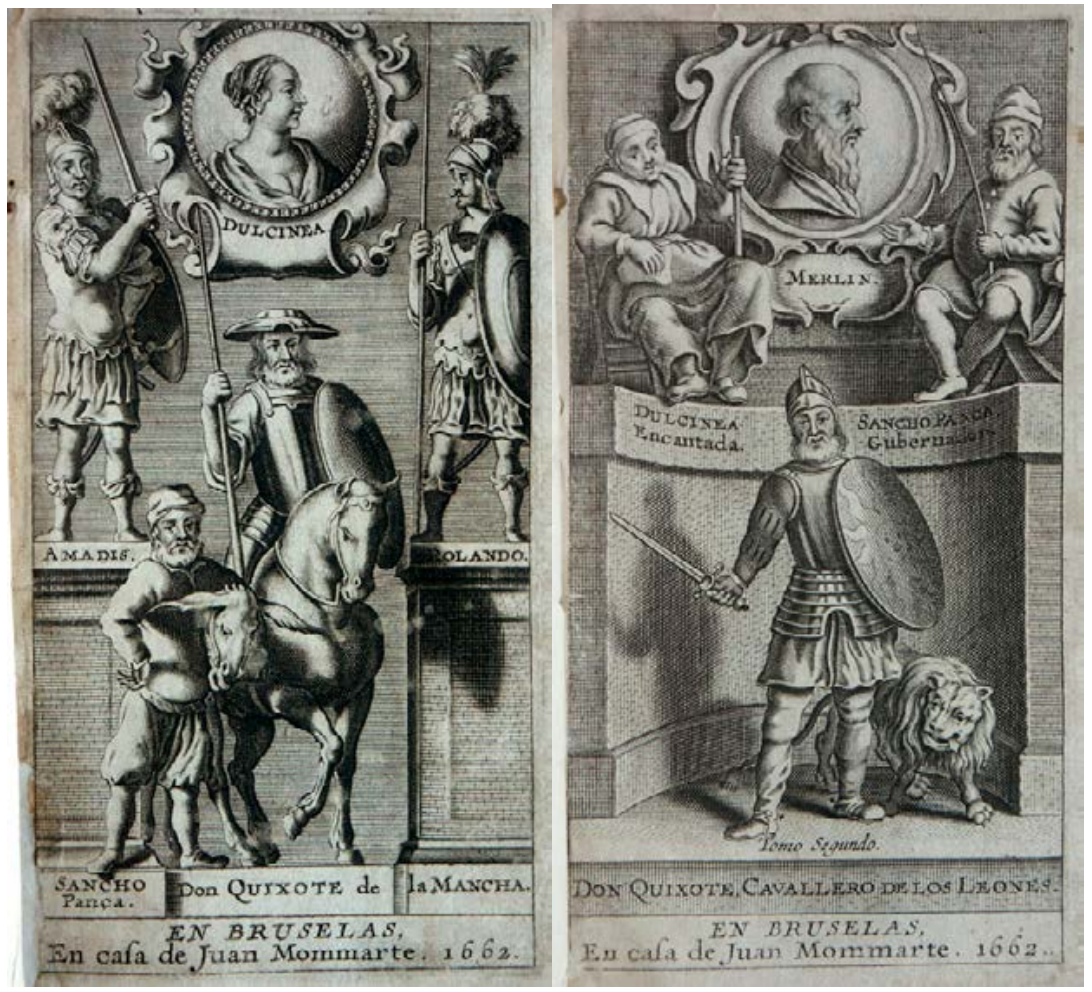

FIGURA 10. Jacob Savery, 1657.

Entendemos, por sus palabras, que Dulcinea no es sino otro nombre para designar la realidad de Aldonza ${ }^{31}$. Compartiendo su lectura en cuanto al con-

30. Edición de 1657, grabado. Dibujante y grabador: Jacob Savery.

31. Interesante a este respecto es apuntar el tema de la polionomasia en el Quijote, que será gran fuente de estudio para muchos especialistas. Veánse Spitzer (1955 y 1962) y Ruiz Pérez (2016). 
tenido de los grabados, no lo estamos en lo referido al segundo de los frontispicios pues, pese a que se etiquete a la aldeana de Dulcinea, es verdaderamente una representación de ese ente físico del que parte ${ }^{32}$ : no puede haber desencanto pues nunca aparece una Dulcinea real a la que encantar, y tampoco una Aldonza.

Hemos de destacar aquí que entre ambos frontispicios advertimos un cambio de concepción del personaje, algo que corre en paralelo a la actitud del propio don Quijote de cara a Dulcinea. Si bien en la primera parte podemos entender que la dama es una condición sine qua non para dedicarse a las armas y cuyas descripciones son más físicas que simbólicas (es el primer frontispicio una representación de esto), en la segunda parte se ha virado y Dulcinea aparecerá más como símbolo que el caballero debe preservar no solo ante los demás personajes (lectores de la primera parte y conocedores, por ende, de la realidad o irrealidad de la dama), sino de la publicación del Quijote de Avellaneda (que, en última instancia, precipitaría esta nueva visión de Dulcinea).

Los frontispicios se irán imitando en los primeros siglos, con apenas variantes, en las principales ediciones ilustradas de la obra. Dulcinea se repetirá así enmarcada, encorsetada, constreñida -bien en la imaginación de don Quijote, para quien existe bajo esa forma idealizada y no carnal, bien según las descripciones de los libros de caballería (que tampoco tienen un referente real)-.

Otro frontispicio, un poco posterior (1780), indica que la forma de representar a Dulcinea cambia, pero no por ello deja de estar encorsetada. Pareciera que don Quijote, pese a tener un referente físico (podríamos decir, una musa que sostiene, muestra y reproduce la idea de Dulcinea) obvia la realidad para centrarse en lo ideado; de ahí que podamos considerarla una imagen especu$\operatorname{lar}^{33}$. Estaríamos así ante el segundo tipo de frontispicios, mucho más elaborados en cuanto a carga simbólica se refiere: si la Dulcinea textual es símbolo, reflejo que parte de Aldonza, representada en un espejo se acerca más a la visión que de ella nos da don Quijote que a la proporcionada por los demás personajes (Fig. 11) $)^{34}$.

\footnotetext{
Nosotros no entraremos aquí por motivos de espacio y porque pensamos que, pese a nacer Dulcinea de una idea física que es Aldonza Lorenzo, en el momento de su creación se hace independiente a ella. Por tanto, no podemos defender que las imágenes que muestren a una aldeana sean representaciones de Dulcinea.

32. Entiéndase aquí que hablamos de ente físico por presuposición. Aldonza tampoco aparece físicamente en la obra, pero el narrador sí le otorga esa realidad corpórea que a Dulcinea le es negada, desde el primer momento, por el propio don Quijote.

33. Lo denominamos frontispicio especular precisamente por la lectura dada: don Quijote prefiere el reflejo a lo reflectante, el contenido al continente.

34. Edición de 1780, grabado. Dibujante: Antonio Carnicero, grabador: Fernando Selma.
} 


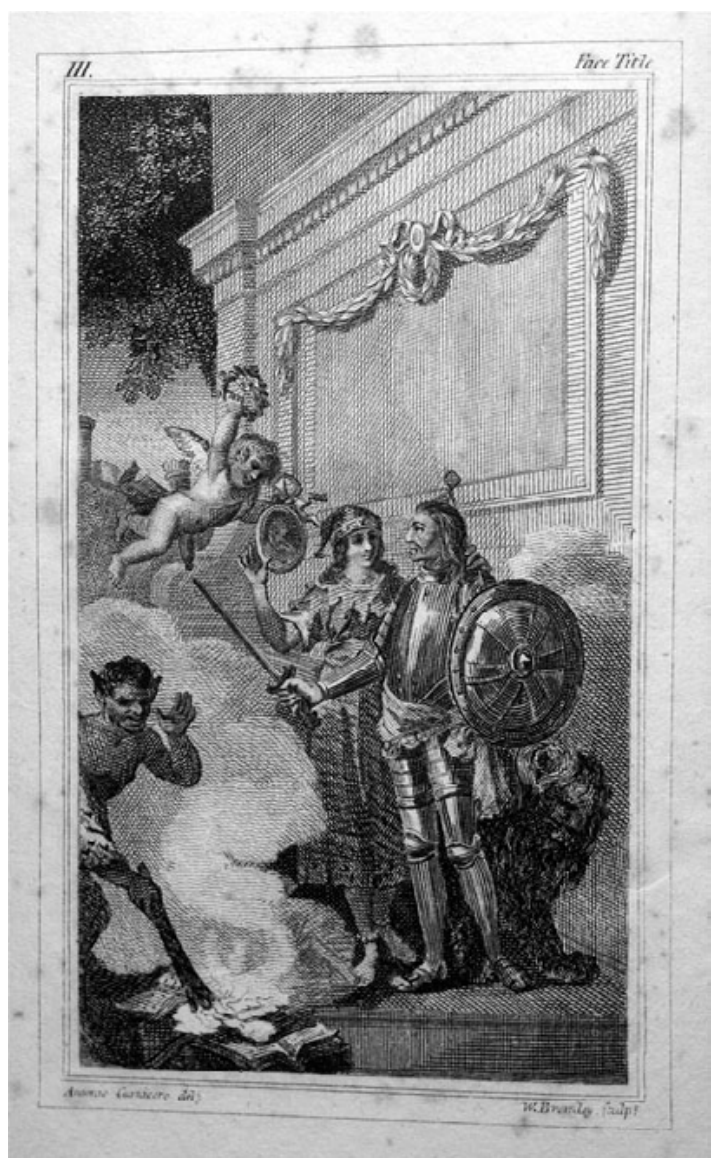

FIgURA 11. Antonio Carnicero, 1780.

También encontramos un esquema similar en el siguiente frontispicio, que representa a Sancho, anclado a la realidad, apuntando a un don Quijote físico y que a su vez mira al cielo, donde un águila sostiene el retrato de la dama de sus pensamientos -bien lejos del suelo, metafisicamente-. Como vemos, estas imágenes se prestan más a la interpretación que las anteriores y siguen la estela del propio texto.

Merece resaltarse que en los frontispicios - cuando aparece en los mismos como la Dulcinea de don Quijote- la dama es siempre una metaimagen, en el sentido en el que se representa en un grabado dentro de un grabado en sí. El paralelismo con el propio libro, donde siendo todo él literatura, Dulcinea es siempre una reflexión metaliteraria, resulta evidente. De alguna manera se ha trasladado esa mise en abyme de la obra a la imagen que lo representa (Fig. 12) ${ }^{35}$. 


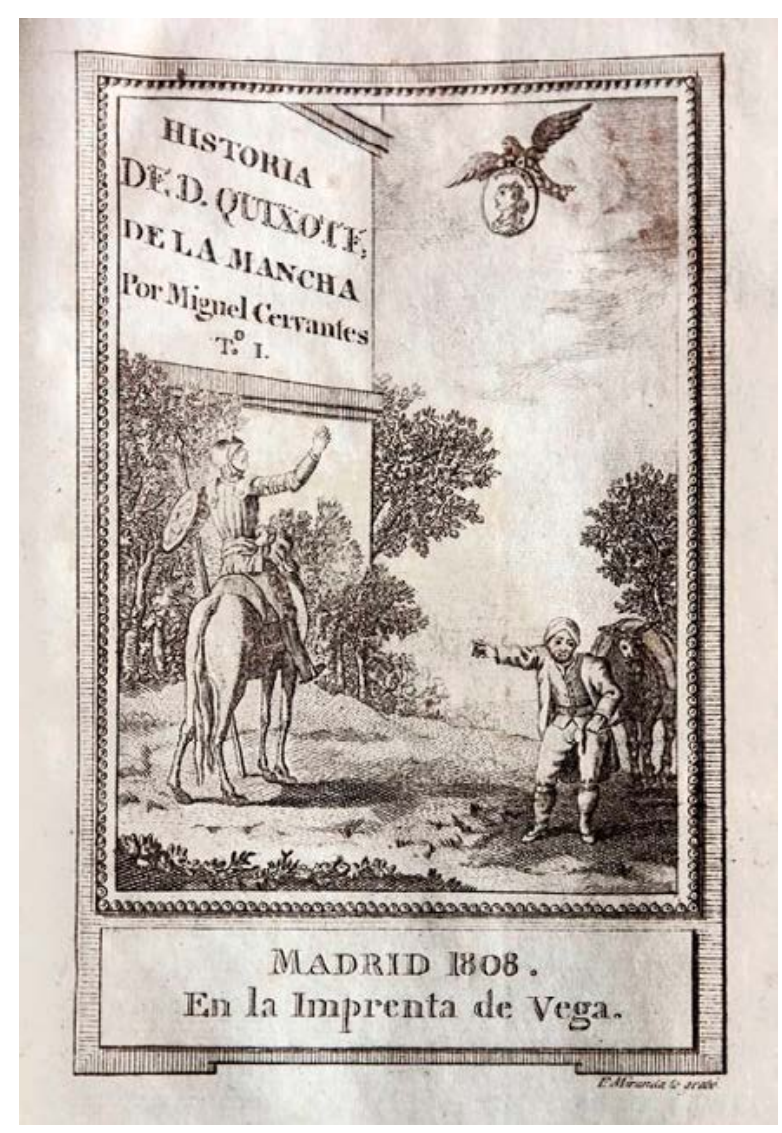

Figura 12. Antonio Rodríguez, 1808.

Ya se avanzaba anteriormente que el asunto de los retratos resulta particularmente complejo. En muchas ocasiones, bajo la imagen aparece un pequeño rótulo donde Aldonza se convierte en Dulcinea. Lo primero que entendemos de esto es que, previo al Romanticismo, la lectura cómica era presuntamente la imperante y que la apoyatura en la idea del enamoramiento de una aldeana por parte de un supuesto caballero era parte de la carcajada. Lo segundo que podemos leer de esto es que el personaje, independientemente de la época, si se quiere representar desde la lectura de don Quijote supone un problema ${ }^{36}$ : el hecho de que no haya un imaginario consolidado en torno a Dulcinea nos

de l'oeuvre sur elle-même, la mise en abyme apparait comme une modalité de la réflexion. Sa propriété essentielle consiste à faire saillir l'intelligibilité et la structure de l'oeuvre. Evoquée par des exemples empruntés à différents domaines, elle constitue une réalité structurelle qui n'est l'apanage ni du récit littéraire, ni de la seule littérature» $(1977,16)$. No nos detenemos aquí, pero lo dejamos apuntado como un tema clave para su posterior estudio.

36. Algunos retratos pertenecen a momentos de la obra donde Dulcinea no llega a verse como aldeana, pero tampoco como Dulcinea misma. Ejemplo de ello es una representación como pastora 
lo corrobora, y más aún si lo comparamos con el hecho de que la mera silueta de caballero y escudero son inmediatamente reconocibles en cualquier lugar, independientemente de la lectura del libro. Dulcinea, por el momento, no ha logrado -y sospechamos que en lo venidero tampoco- una marca iconográfica que la haga identificable.

Podemos destacar como retrato de la amada la imagen que ofrecemos. En ella, Alonso Quijano tiene sobre la mesa los libros de caballerías (se trata no de un frontispicio sino de una imagen que ilustra el capítulo I, I) que le dan la inspiración para crear a Dulcinea del Toboso. De ahí que una musa le insufle la idea de la amada mientras se la muestra a través de un retrato encorsetado en un marco ${ }^{37}$. Podemos calificar esta representación de imagen especular por dos motivos: el primero de ellos, porque pareciera un reflejo de la musa (lo que le inspira, lo que le mueve); el segundo, porque como la musa, es algo inalcanzable (Fig. 14) ${ }^{38}$.

fingida que pulula por la también fingida Arcadia, en la edición de 1836-1837, cuyo dibujante fue Tony Johannot y el grabador Henri Désiré Porret (Fig. 13).

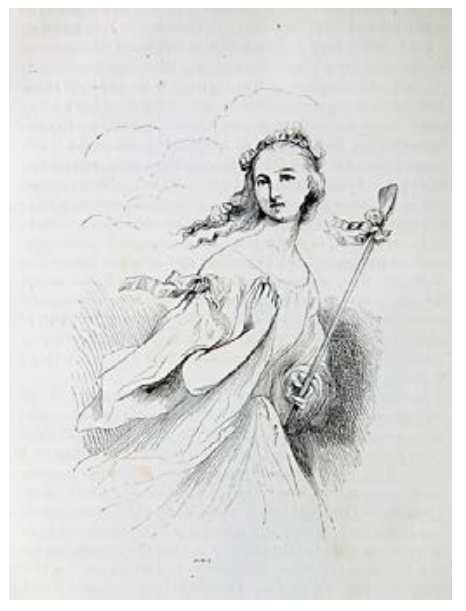

FIGURA 13. Tony Johannot, 1836-1837.

37. De ánima (alma) procede la capacidad de animar, esto es, dar vida (insuflarla). Creemos que esta característica es definitoria de nuestro hidalgo en tanto que anima a don Quijote, y de don Quijote en cuanto que anima (en un plano metafórico, pues se trata de una idea) a Dulcinea. Así, además: «Bien podrán los encantadores quitarme la ventura, pero el esfuerzo y el ánimo es imposible» (II, XVII, 677). Sobre ánima, en la nota 38 de los comentarios de Herrera a Garcilaso de la Vega -con-

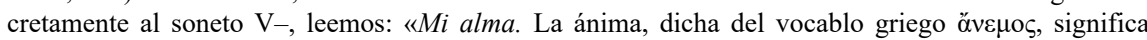
espíritu, porque no se puede vivir sin espiración. De ésta dice San Agustín en el de espíritu y ánima, cap. 34, si él escribió este libro, que cuando anima al cuerpo y le da vida se llama ánima; mientras quiere, ánimo; en tanto que está vestida de ciencia y ejercita la destreza y sabiduría de juzgar, mente; cuando se acuerda, memoria; discurriendo y discirniendo cada una cosa, razón; afixando en la contemplación, espíritu, y en tanto que posee y señorea la fuerza de sentir, se apellida sentido. Todas éstas son diversas potencias de la ánima con que declara y pone en obra y ejercicio sus acciones»; edición de Gallego Morell (1972, 325).

38. Edición de 1798-1799, viñeta. Dibujante: Luis Paret y Alcázar, grabador: Juan Moreno Tejada. 


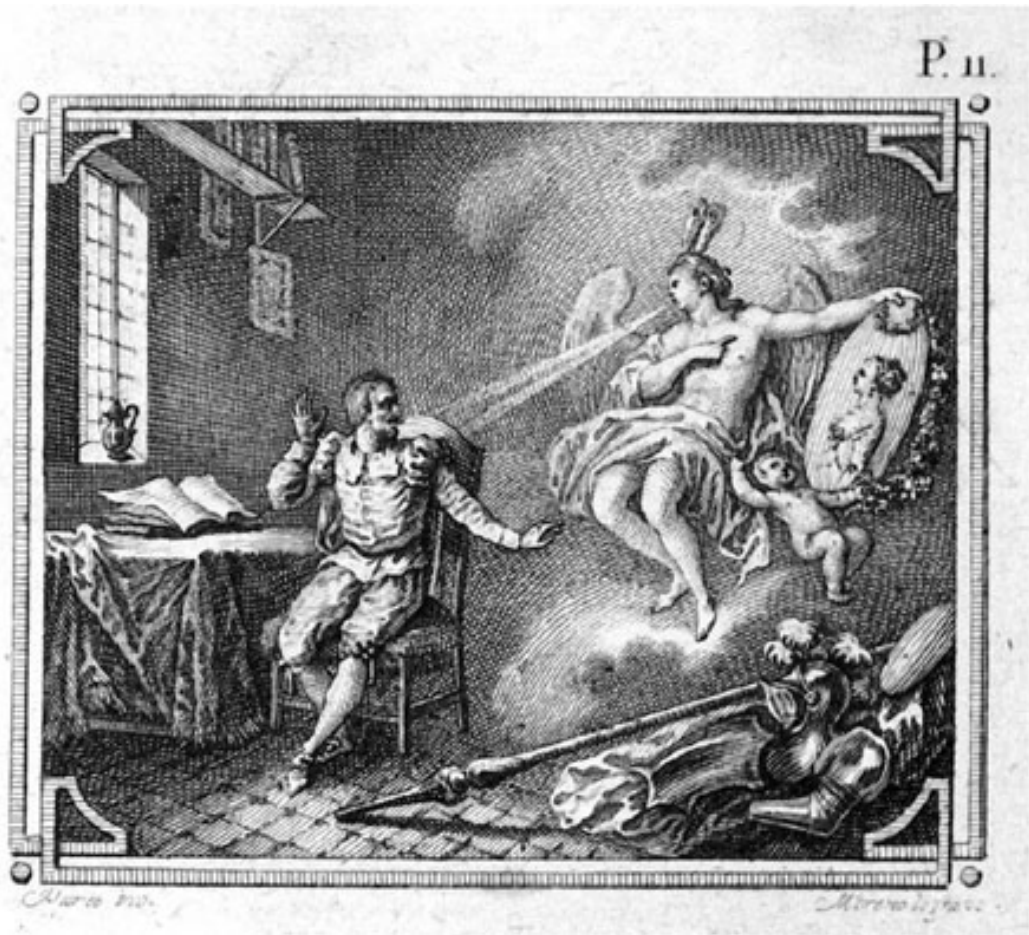

FIgURA. 14. Luis Paret y Alcázar, 1798-1799.

Debemos detenernos aquí para hacer unas consideraciones de las últimas pinturas en conjunto. De los frontispicios e imagen, todos, salvo el de Jacob Savery, son -en la medida en la que puede serlo la pintura- autorreferenciales: siempre un personaje representado apuntará al cuadro, a la imagen encorsetada de Dulcinea. Esta suerte de llamada, donde el grabado o la ilustración aluden a sí mismos (y que nos invitan, como Borges, a pensar que, si Dulcinea es un personaje de ficción dentro de la ficción, también nosotros podemos serlo), es una de las características que Ana María Dotras da a la novela de metaficción ${ }^{39}$.

Siguiendo el paralelismo entre la novela y sus ilustraciones, esto nos lleva a pensar que, no sin dificultades, el personaje fue pronto comprendido en una especie de mecanismo o juego de cajas chinas donde, si dentro de la literatura que es la novela Dulcinea era literatura creada por don Quijote, para la pintura no podía ser sino una pequeña imagen dentro del conjunto pictórico.

Por tanto, como retratos propiamente dichos de Dulcinea -o que pudiéramos considerar de Dulcinea- encontramos estas imágenes encorsetadas, prin-

39. Dotras la define como «aquella que se vuelve hacia sí misma y, a través de diversos recursos y estrategias, llama la atención sobre su condición de obra de ficción y pone al descubierto las estrategias de la literatura en el proceso de creación» $(1994,27)$. 
cipalmente en los frontispicios que abren el libro (que son, dentro de la tipología de representaciones de nuestro personaje, el modelo que presenta una mayor dificultad). Esto es curioso, sobre todo si pensamos que desde el XIX será complicado encontrar una imagen de Dulcinea que no pertenezca a la representación de un episodio y que la muestre en exclusiva, tal vez porque desde el Romanticismo se entienda que es un personaje únicamente existente en la mente de los otros, y que cada cual presenta de ella una imagen distinta, como diferentes son los reflejos.

De este modo, a diferencia de otros personajes de la obra, podemos corroborar que Dulcinea no ha alcanzado una imagen que logre identificarla de manera inequívoca y universal -como sí lo han logrado las figuras de don Quijote y Sancho- ${ }^{40}$. Si bien hay más ilustraciones de Aldonza que de Dulcinea, esta, al estar construida sobre un estereotipo costumbrista, se liga -en sus versiones y recreaciones diversas- al motivo cómico. Suponen por ello lo más representado en una época en la que el Quijote era sobre todo (y supuestamente) un libro que buscaba la carcajada.

Por otro lado, el hecho de que no se haya consolidado una «imagen tipo» en torno a Dulcinea no resulta del todo sorprendente si advertimos también el escaso número de representaciones que se han hecho del personaje en general -en comparación siempre a la abundancia de grabados, ilustraciones, pinturas y similares que hay de otros actantes de la obra-. Creemos que, como se ha justificado anteriormente, esto se debe a la dificultad interpretativa de un personaje casi imposible de concebir más allá del pensamiento, que, insistimos, no aparece físicamente en la obra (ni como aldeana ni como dama) y que se basa únicamente en diversos discursos de lo que otros dicen de ella. Su plasmación en papel implica que el pintor se ajuste de forma inmediata a una u otra lectura -paródica, sublime-, sin posibilidad de enmienda.

Por tanto, la investigación iniciada en este trabajo nos ha llevado a la conclusión de que es Dulcinea, tal como se presuponía, uno de los personajes más complejos del Quijote de cara a establecer una biografía literaria. Aceptándola como personaje, el hecho de que su misma figura pueda nacer de muy diversos esquemas -según el punto de partida de cada crítico o ilustradorimplica que haya sido leída desde ópticas tan variadas como posibilidades ofrece la novela.

Postulamos así que esta complejidad se debe a que Dulcinea ha de ser entendida siempre como un ente proteico y multiforme, imposible de conciliar en una única lectura, pues representa en sí misma-como elipsis, ausencia y

40. Incluso entrando en contradicción con el propio texto. El imaginario, una vez consolidado en torno a ellos, se hace prácticamente inamovible pese a que la obra diga lo contrario. Sírvanos como ejemplo el propio texto [I, IX]: «Junto a él estaba Sancho Panza, que tenía del cabestro a su asno, a los pies del cual estaba otro rétulo que decía "Sancho Zancas", y debía de ser que tenía, a lo que mostraba la pintura, la barriga grande, el talle corto y las zancas largas, y por esto se le debió de poner nombre de "Panza" y de "Zancas", que con estos dos sobrenombres le llama algunas veces la historia», cuya explicación a por qué no se ha generado una imagen de Sancho con las piernas largas parece sencilla en tanto que el propio narrador olvida denominarlo así en lo que resta de texto. 
presencia todo en uno- la metáfora de la propia ficcionalidad de la obra, de la propia literariedad. Y, como tal, ha de ser entendida como un ser que, pese a nacer de la aldeana, actúa y opera en texto e imágenes de manera independiente a Aldonza Lorenzo.

\section{BIBLIOGRAFÍA CITADA}

Albert, Georgia. 1993. «Understanding Irony: Three Essais on Friedrich Schlegel». Modern Language Notes 108 (5): 825-843.

Allen, John Jay. 1990. «El desarrollo de Dulcinea y la evolución de don Quijote». Nueva revista de filología hispánica 38 (2): 849-856.

Alonso Vázquez, María Cristina. 2007. «Los molinos de viento vistos por algunos ilustradores europeos del Quijote». En Don Quijote por tierras extranjeras. Estudios sobre la recepción internacional de la novela cervantina, ed. Juan Bravo Castillo, 277-302. Cuenca: Colección Humanidades.

Benéitez Andrés, Carmen. 2016. «El concepto de ironía en la estética de Friedrich Schlegel: contexto y recepción». Daimon. Revista Internacional de Filosofía 67: 39-55.

Canga Sosa, Manuel Ángel. 2008. «La imagen fantasmática de Dulcinea en el discurso amoroso del Quijote». En Tus obras los rincones de la tierra descubren: actas del VI congreso internacional de la Asociación de Cervantistas, 215-224. Alcalá de Henares.

Comellas, Mercedes. 2002. «Sátira contra ironía o la sinceridad de la ficción literaria: una dialéctica romántica». En Estudios de literatura comparada. Norte y sur. La sátira. Transferencia y recepción de géneros y formas textuales, coord. José Enrique Martínez Fernández, 281-293. León: Universidad de León.

Dällenbach, Lucie. 1977. Le récit spéculaire. Essai sur la mise en abyme. París: Collection Poétique aux Éditions du Seuil.

Dotras, Ana María. 1994. La novela española de metaficción. Barcelona: Ediciones Júcar.

Frenk Alatorre, Margit. 2005. Entre la voz y el silencio: la lectura en tiempos de Cervantes. México: Fondo de Cultura Económica.

Gallego Morell, Antonio. 1972. Garcilaso de la Vega y sus comentaristas. Madrid: Gredos.

Genette, Gérard. 1969. Figures II. París: Seuille.

Gorla, Paola Laura. 2009. «Los encantos de Dulcinea». Letras de Deusto 120 (38): 9-29.

Gutiérrez, Fátima. 2012. Mitocrítica. Naturaleza, función, teoría y práctica. Lérida: Editorial Milenio.

Lacan, Jacques. 1998. Seminario 1. Los escritos técnicos de Freud. Barcelona: Paidós.

Lamberti, Mariapia. 2011. «Dulcinea o el ideal». En Visiones y revisiones cervantinas: actas selectas del VII Congreso Internacional de la Asociación de Cervantistas, coord. Christoph Strosetzki, 421-432. Alcalá de Henares.

Lucía Megías, José Manuel. 2006. Leer El Quijote en imágenes: hacia una teoría de los modelos iconográficos. Madrid: Calambur.

Luttikhuizen, Frances. 2008. «La primera edición ilustrada del Quijote (Dortrecht, 1657), un libro de emblemas». En Cervantes y las religiones. Actas del Coloquio Internacional de la Asociación de cervantistas, 283-300. Israel.

Martín, Antonio. 2011. «Las Aleluyas, primera lectura y primeras imágenes para niños en los siglos XVIII-XIX. Un antecedente de la literatura y la prensa infantil en España». Espéculo: Revista de Estudios Literarios 47. Accesible en: <http://webs.ucm.es/info/ especulo/numero47/aleluya.html $>$. Fecha de acceso: 22 de octubre de 2020. 
Miguel-Pueyo, Carlos. 2006. «El Quijote: entre lectura colectiva y lectura silenciosa». En El Quijote en Buenos Aires: lecturas cervantinas en el cuarto centenario, eds. Alicia Parodi, Julia D’Onofrio y Juan Diego Vila, 469-476. Buenos Aires: Instituto de Filología y Literaturas Hispánicas "Dr. Amado Alonso".

Moner, Michel. 1989. Cervantes conteur. Écrits et paroles. Madrid: Casa de Velázquez.

Ricoeur, Paul. 2003. La memoria, la historia, el olvido. Madrid: Editorial Trotta.

Ruiz Pérez, Pedro. 2016. «Anonimia, polionomasia y nombradía en Don Quijote y Cervantes». Criticón 127: 11-30.

Schlegel, Friedrich. 2009. Fragmentos. Barcelona: Marbot.

Spitzer, Leo. 1955. «Perspectivismo lingüístico en el Quijote». En Lingüistica e historia literaria, 161-225. Madrid: Gredos.

Spitzer, Leo. 1962. «On the Significance of Don Quijote». Modern Lenguage Notes 77 (2): 113-129.

Torres Lázaro, Julio. 1997. «Dulcinea del Toboso. El personaje elíptico». Revista de filología románica 14 (2): 441-456.

Urbina, Eduardo. 2005. «Don Quijote, libro ilustrado». Contrastes: revista cultural 38: $37-41$.

Zoppi, Federica. 2016. «Los libros de caballerías, el Quijote y la lectura». Historias fingidas 4: 167-188.

Zumthor, Paul. 1991a. «La poesía y la voz en la civilización medieval». En Historia y crítica de la literatura española, vol 1/1. Edad Media, coord. Francisco Rico, 21-25. Barcelona: Editorial Crítica.

Zumthor, Paul. 1991b. Introducción a la poesía oral. Madrid: Taurus Humanidades.

Zumthor, Paul. 2006. La poesía y la voz en la civilización medieval. Madrid: Abada.

Recibido: 22 de abril de 2019

Aceptado: 23 de septiembre de 2019 